\title{
The Land Question and Catholic-Anglican Relations in Buha, Western Tanzania: The White Fathers and C.M.S. Experience,
} 1934-1959

\author{
Salvatory Stephen Nyanto \\ University of Iowa, Iowa City, USA \\ University of Dar es Salaam, Dar es Salaam, Tanzania
}

\begin{abstract}
Land was important — in the course of spreading and seeking new converts — for both Missionaries of Africa (White Fathers) and Church Missionary Society (C.M.S.) in Buha, Western Tanzania. This paper examines the land question as one of the challenges that the White Fathers encountered in their attempt to evangelize communities in Western Tanzania. I argue that the land question remained throughout the late-colonial period one of the unresolved issues, and at some mission stations, impeded the activities of the White Fathers and C.M.S. missionaries. This paper relies on archival documents first, to examine the land question and White Fathers-C.M.S. relations in Buha from 1934 to 1959 . Second, I intend to demonstrate the fact that land issues remained at the heart of the missionary enterprise in Buha. Both Catholic and Anglican missionaries were determined to have more mission plots for medical, education and religious purposes.
\end{abstract}

Keywords: land question, White Fathers, C.M.S., Buha

\section{Introduction and Overview of Missionary Societies in Buha, Western Tanzania}

This paper, based on archival sources, views the land question as a window to examining Catholic-Anglican relations in Western Tanzania. ${ }^{1}$ The paper, specifically, views the land question as one of the challenges that the White Fathers and C.M.S. missionaries encountered in their attempt to evangelize the people of Western Tanzania. I argue that land-related problems remained throughout the late-colonial period, one of the unresolved issues and at some mission stations, one that hindered the activities of the White Fathers and missionaries of the Church Missionary Society (C.M.S.). Notwithstanding the growing tensions between the two missionary societies, local Chiefs and the people were not aware of such conflicts. While the majority Chiefs had - at the time of the contact with the C.M.S. missionaries - already converted into Catholicism, they did not oppose to the establishment of the activities of the C.M.S. in Buha. Religious rivalries, as I will demonstrate in due course, might have been driven by the fear of protecting "missionary spheres of influence"

\footnotetext{
*Paper presented at the annual conference of the American Catholic Historical Association in Atlanta-Georgia on the theme "The Politics of Ecumenism: Catholic-Anglican Relations in Twentieth-Century East Africa”, Friday January 08, 2016.

Salvatory Stephen Nyanto, Ph.D., (History) candidate in University of Iowa; assistant lecturer in University of Dar es Salaam.

1 During the German colonial period, what is today Tanzania mainland was part of German East Africa. After the First World War, Germany lost the colony to the British who adopted Tanganyika as a name of the colony. Three years after independence (i.e. 1964), Tanganyika and Zanzibar united to form Tanzania. "Tanganyika" will be used throughout the paper.
} 
in Western Tanzania. In the course of striking a balance between the White Fathers and C.M.S. missionaries, the British colonial state addressed land conflicts on the basis of the influence of each Missionary society in Buha.

This paper relies on archival documents first, to examine the land question and Catholic-Anglican relations in Buha from 1934 to 1959. Secondly, I intend to demonstrate the fact that land issues remained at the center of the missionary enterprise. This explains why each missionary society was determined to have more mission plots for medical, educational and religious purposes. In order to meet the central objective of the subject matter, the paper will address four issues. First, it will present an account of the struggle for land between the White Fathers and C.M.S. missionaries in Buha and the resultant tensions among the two missionary societies. Second, I will explore government responses in addressing the tensions over land between the White Fathers and C.M.S. missionaries. Third, the paper will examine the provision of rights of occupancy to missionaries' applications and how, in some contested areas, colonial officials delayed or used their power to manipulate the situation by favoring missionaries who had already voiced their concerns over the areas. Finally, the paper will provide an account of the land question centering on the White Fathers, native affairs, and the colonial state to argue that problems over land - in some areas of Western Tanzania-were not limited to the White Fathers and C.M.S. missionaries. In some instances, the White Fathers interfered natives' plots that, too, needed government intervention.

Buha refers to a region in Western Tanzania that today comprises of the Kigomaad ministrative region. In the pre-colonial and post-colonial periods, the region of Buha consisted of six independent chiefdoms: Heru, Nkalinzi, Heru-Bushingo, Luguru or Kukanda, Muhambwe and Buyungu. In comparison to other kingdoms, Heru was the largest and most populous kingdom. ${ }^{2}$ Apart from the multiplicity of centralized chiefdoms, Buha is one of the regions in Tanzania that received many Western religious institutions, and their influence remains to this day. The German Protestant Breklum Mission was the first missionary society to open up a mission station in the interior of Buha, during the German colonial period. However, after the First World War, this society did not continue with its mission. Its mission buildings were taken over by another German Missionary Society, the Lutheran Neurkirchen Mission. ${ }^{3}$

Other missionary societies - that opened up their mission stations after the First World War in Buha-were the French Catholic White Fathers and White Sisters. The two missionary societies were founded by Cardinal Charles Lavigerie in 1868 and 1869 with a specific motive of evangelizing the heart of Africa. ${ }^{4}$ The Anglican missionaries of C.M.S. ventured into Buha in 1934 to take over the work of the Lutheran Neurkichen Society at Kikangara, Kihwahuro, and Kilungwe mission stations. Apart from the C.M.S.

\footnotetext{
2 Johan H. Scherer, "The Ha of Tanganyika", Anthropos, Bd. 54, H.5./6. (1959), p. 844, Captain C.H.B. Grant, "Uha in Tanganyika Territory”, The Geographical Journal, Vol. 66, No. 5 (1925), p. 412.

3 Johan H. Scherer, The Ha, pp. 898-899.

4 Jean-Claude Ceillier, Histoire des Missionnairesd'Afrique (PèresBlancs) e la fondation par MgrLavigerie à la mort du fondateur (1868-1892) (Paris: editions Karthala, 2008), pp. 224-225, History of the Missionaries of Africa (White Fathers): From the Beginning of their Foundation by Msgr. Lavigerie until his Death. Translated from French by Aylward Shorter (Nairobi: Paulines Publications Africa, 2011), p. 15, Francis P. Nolan, Mission to the Great Lakes: The White Fathers in Western Tanzania 1878-1978 (Kipalapala: Tanganyika Mission Press, 1978), p. 17. The White Fathers in Colonial Africa, $1919-1939$ (Nairobi, 2012), Jacqueline Paulhus, Go to My People: Missionaries in Tanzania, 1894-1994 (Missionary Sisters of Our Lady of Africa, 1994). (anonymous), Directoire pour l'observance des Constitutions des Sœurs Missionnaires de Notre-Dame d'Afrique (Alger, 1938), p. vii, Lucas Malishi, Introduction to the History of Christianity in Africa (Kipalapala: Tanganyika Mission Press, 1987), p. 127, Peter van de Pas, A History of the White Fathers in Western Tanzania: Their work in the Vicariate of Tanganyika With Special Emphasis on Today's Diocese of Sumbawanga and Mpanda, 1878-2002 (Dar es Salaam: Atiman House, 2010 ), p. 16.
} 
missionaries, the Swedish (Pentecostal) Free Mission opened up the first mission station at Msambara in 1933 under the auspices of an American missionary called D.F. Spies. After the Second World War, missionaries of the Seventh-Day Adventists began their work in Buha, making them the last missionary society to arrive during the colonial period. By the mid-1940s, many areas in Western Tanzania had already been integrated into Christian faiths. ${ }^{5}$

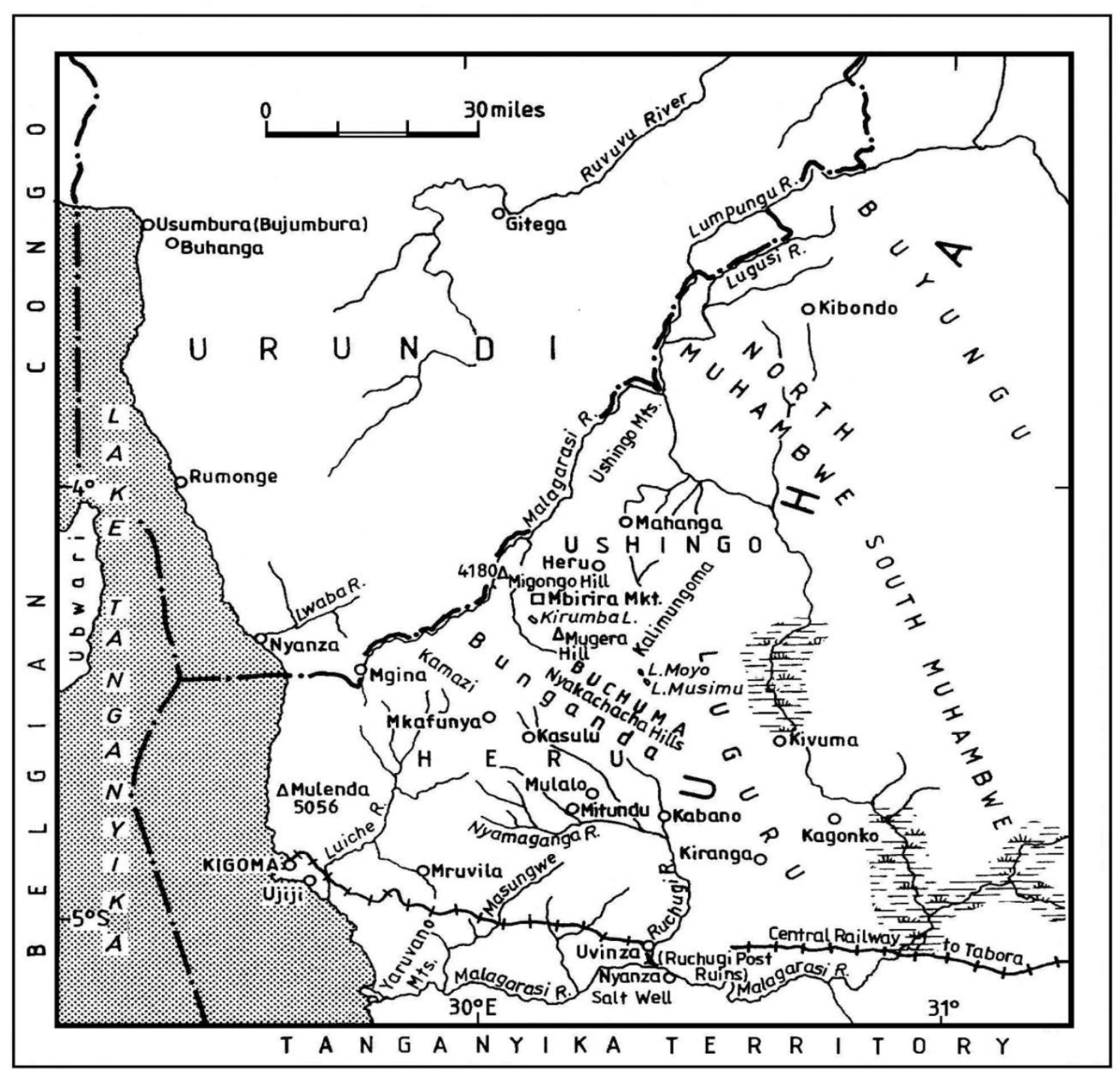

Figure 1. Buha, which forms part of Kigoma region in Western Tanzania.

Source: Modified from Johan H. Scherer, "The Ha of Tanganyika”, 1959, p. 902; Captain C. H. B. Grant, "Uha in Tanganyika Territory", 1925, p. 413.

\footnotetext{
5 Johan H. Scherer, “The Ha”, p. 899, Simon Kakete et al., "Kanisa la Pentekoste Bigabiro, Jubilii 1935-1985” (Bigabiro, unpublished manuscript, 1985), p. 14.
} 


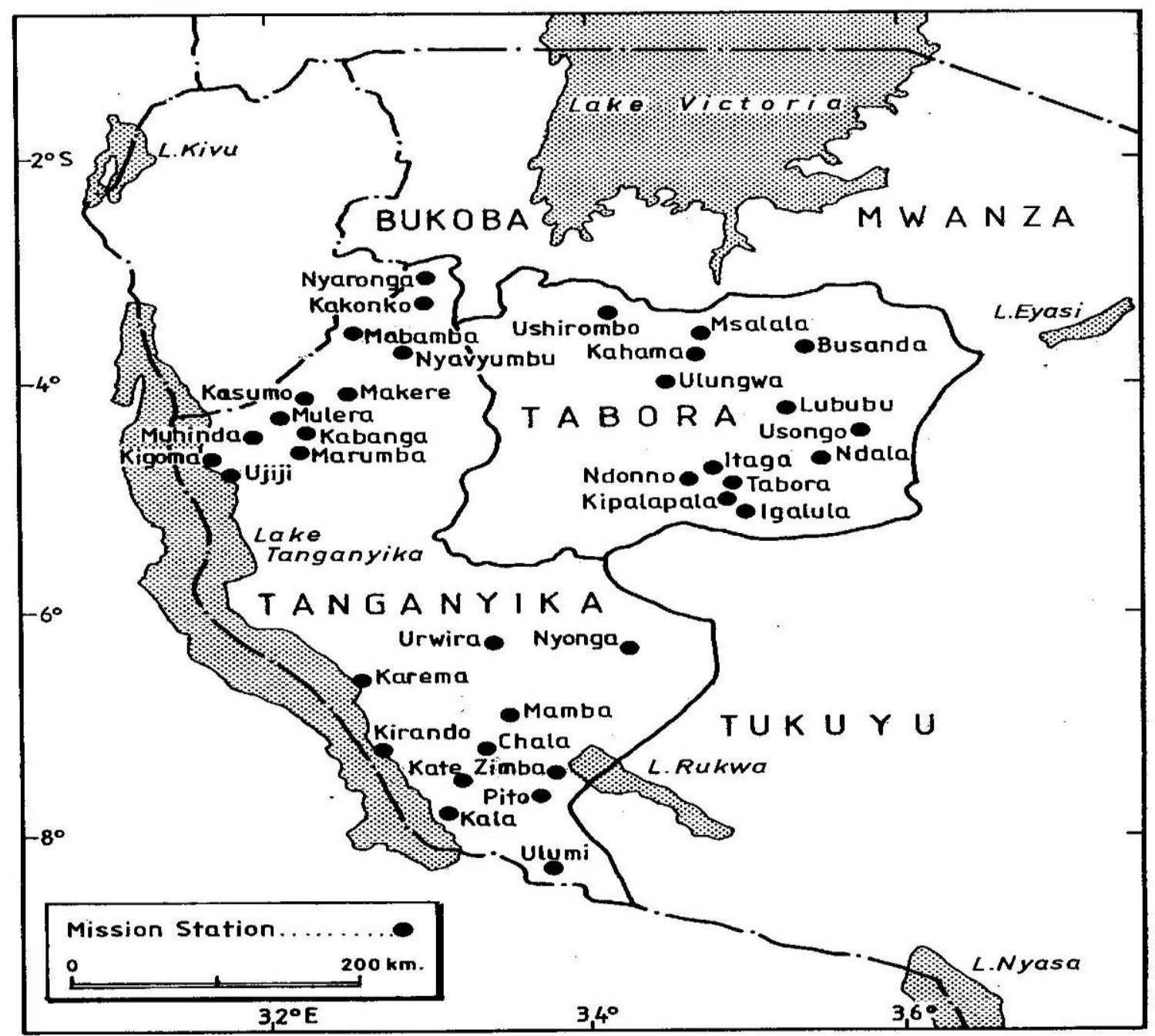

Figure 2. Catholic Mission Stations in Western Tanzania up to 1950.

Source: Hugo Hinfelaar, Footsteps on the Sands of Time: A Life of Bishop Jan van Sambeek, 2007, p. 34; Georg Leisner and Ludovick Matanwa, Miaka Mia Jimboni Kigoma 1879-1979, 1979, pp. 14-15.

\section{Land and the Struggle for "Religious Spheres of Influence": White Fathers and C.M.S. in Buha, 1934-1959}

The struggle for land in Buha began in 1934 when C.M.S. missionaries applied for land to establish new mission stations. Following the C.M.S. proposal—of establishing new mission station in Buha-the Provincial Commissioner of Western Province, F. J. Bagshawe, was hesitant as to whether he should allow or reject the missionaries' entry into Buha. He expressed his worries to the Chief Secretary of the Tanganyika territory saying that he could not solve the missionary problem alone, "There remains to be settled the questions whether the CMS Society is to be persuaded or prevented from entering Buha, and I have already informed you that for reasons, I do not want to settle this myself." What accounted for his worries was the fact that there was a danger of overlapping missionary interests in the areas of Nyavyumbu, Kagera, Heru-Ushingo and Rungwe where there were not yet schools. But in Muhunga, the White Fathers had a school and the C.M.S. wanted to 
open up one school. In addition to schools in Buha, the White Fathers had already established a boarding school at Ujiji with 35 students, a few of whom had already been speaking English. ${ }^{6}$

Apart from school establishments, the White Fathers' influence rested on the fact that they had already mastered the local language — Kiha — and they had for years been studying local affairs. Furthermore, the most important of the seven Chiefs of Buha, Mwami Joseph Gwassa, had already been converted into Catholicism and the other two Chiefs were on good terms with the White Fathers. ${ }^{7}$ In their attempt to protect their influence, Bishop Birraux of the vicariate apostolic of Tanganyika - in response to the Provincial Commissioner's question about the C.M.S. - wished that they would not go to Buha but he insisted that he would do his best to avoid frictions with the Anglican missionaries. But as the Acting Governor, Mr. Woodhouse noted, the idea of forming "religious spheres of influence" in Buha was unsuccessful. Rev. Bakewell along with other C.M.S. missionaries had proposed to bring to Buha two brand new Church Army men from England to compete with the White Fathers. ${ }^{8}$

To avoid friction between the White Fathers and C.M.S. missionaries in Buha, the Provincial Commissioner suggested three things. First, he persuaded Rev. Backewell of the C.M.S. missionaries not to establish their mission stations in concentrations where the White Fathers had already established themselves. Instead they were supposed to establish themselves in areas where the influence of the White Fathers was not strong. ${ }^{9}$ Second, he suggested the use of the land law to prevent mission rivalry in areas where local chiefs and the people did not wish the appearance of the second mission. Third, since the White Fathers had already voiced their concerns over many areas and since they had already established themselves in the region, their applications had to be given priority whenever applications overlapped. It was also the case that where the C.M.S. had already voiced their concerns over particular areas, their applications were to be given priority too. ${ }^{10}$

Before the C.M.S. showed interests in Buha, the Provincial Commissioner authorized Bishop Birraux of the vicariate apostolic of Tanganyika to carry on with his work without waiting for formal procedures. This was due to the fact that the White Fathers was the only strong missionary society in the area. ${ }^{11}$ Following the desire of the C.M.S. missionaries for mission plots in Buha, the Provincial Commissioner was keen to accept or reject applications for new mission plots in favor of the first missionary society that had voiced its interests. For instance, the Assistant District Officer of Kasulu District - that also included the today's Kibondo District - rejected the C.M.S. applications for mission plots at Mugunzu and Mabamba because the White Fathers had already established themselves along the Kibondo-Mugunzu-Kasana route with mission stations and schools. Commenting on the White Fathers' priority over the C.M.S. missionaries in Kibondo area, the Assistant District Commissioner of Kasulu said,

\footnotetext{
6 TNA 180/C32 Vol. 1, Letter to Honourable, the Chief Secretary to the Government, Tanganyika Territory, Confidential No. 43/39/22 Jan 3rd, 1934.

7 Ibid. Mwami was the title of Chiefs or Kings of Heru, Nkalinzi, Heru-Bushingo, Nkanda-Luguru, Muhambwe and Buyungu in Buha.

${ }^{8}$ See TNA 180/C 32 Vol. 1, No. 43/39/22 Jan 3rd, 1934, Mr. Woodhouse's reply to F. J. Bagshawe on behalf of the Acting Governor, Tanganyika Territory.

9 TNA 180/C32 Vol. 1, Letter to the Honourable the Chief Secretary to the Government, Tanganyika Territory, Confidential No. 43/39/22 Jan 3rd, 1934.

${ }_{10}$ TNA 180/C 32, Vol. 1, No. 43/39/29, 12th February, 1934.

11 TNA 180/C 32, Vol. 1, No. 45/39/17, Letter from the Provincial Officer to the Honourable Land Officer, Tanganyika Territory, 26th April, 1934.
} 
The claims of different mission societies receive every consideration but I consider that there is no room for another society along this route and I recommend that the C.M.S. application for plots at Muguzu and Mabamba be refused and further that none be granted to this society in this particular area. I believe such a step to be in the best interest of all, including those of the Church Missionary Society. ${ }^{12}$

While the colonial state gave priority to the White Fathers in the Kibondo area in some places, especially in Kasulu, it favored the C.M.S. missionaries because they had already established themselves in the town. For instance, in 1935, Fr. Pineau and Br. Emile wanted to open up a mission station at Kimobwa near Boma [the District headquarters]. But the British colonial state refused to let the White Fathers build a mission station at Kimobwa because the C.M.S. missionaries had already set up their mission station in the town. As a result, the White Fathers withdrew their interest and as an alternative to the failed plan, they opened up their mission station at Kabanga about five miles from the town. ${ }^{13}$ They also opened another station at Uvinza, which however was abandoned in 1957. Eventually, the White Fathers returned to Kasulu in 1959 after so many years of opposition from the colonial state. A similar case occurred in Kibondo where it was not easy for Fr. Van den Dobblesten to secure a place in the town because the C.M.S. missionaries had already become influential. It was not until 1959 that the colonial state allowed them to open up their station a few miles from the town. ${ }^{14}$

It should, however, be noted that notwithstanding the growing tensions between the two missionary societies - as the Provincial Commissioner had expressed in his concerns - it seems that both Chiefs (of all six chiefdoms) and the people were not aware of religious rivalries between the two missionary societies. Neither were they opposed to the establishment of the activities of the C.M.S. in Buha where the majority chiefs were on good terms with the White Fathers. Only a few natives-as F. J. Bagshawe noted-were aware of such tensions. Religious contentions between the White Fathers and the C.M.S. missionaries seem to have been driven by the fear of protecting "missionary spheres of influence" in Western Tanzania. ${ }^{15}$ It was not therefore a fear that involved the local population. Had the conflicts transcended the boundaries of missionaries to involve local Chiefs and their people, the Provincial Commissioner of Western Province [F. J. Bagshawe], would have taken stern measures to prevent Chiefs' and people's discontent against any mission in favour of the other in Buha. Commenting on the absence of local awareness of the rivalries between the White Fathers and C.M.S. missionaries, the Provincial Commissioner made the following observation.

With reference to His Excellency's minute "the chiefs and people are not genuinely opposed" to the intervention of the CMS for they do not know what is proposed. Few of them realise that such a thing as religious rivalry exists, for they do not take the Neurkirchen Society, represented only by Germans, seriously. I am most anxious to prevent anything like an organised expression of native opinion for or against any Mission. ${ }^{16}$

\section{Missions and Rights of Occupancy in Buha: Government Interventions}

In order to prevent unnecessary tensions between the White Fathers and C.M.S. over land issues in Buha, His Excellency the Governor of Tanganyika territory, ordered all Provincial Commissioners that missionary

12 TNA 180/C 32, Vol. 1, No. C/1, letter from the Assistant District Officer of Kasulu to the Provincial Commissioner, 5th June, 1934.

${ }^{13}$ Georg Leisner and Ludovick A. Matanwa, Miaka Mia Jimboni Kigoma 1879-1979 (Tabora: Tanganyika Mission Press, 1979), p. 33 .

14 Ibid, p. 37.

15 See TNA 180/C 32 Vol. 1, No. 43/39/22 Jan 3rd, 1934, Mr. Woodhouse's reply to F. J. Bagshawe on behalf of the Acting Governor, Tanganyika Territory.

16 TNA $180 / \mathrm{C} 32$ Vol. 1. 
societies could not be allowed to occupy any further plots until they applied for rights of occupancy. The governor further insisted that missionaries were supposed to submit applications for rights of occupancy for all areas they had already occupied and built schools and that the applications had to be rigidly scrutinized by all parties involved before the issuance of the rights of occupancy. ${ }^{17}$ Such rigorous procedures over the already built up areas were intended to prevent further occurrence of missionary tensions over the land. Following the Governor's order, the Provincial Commissioner-F. J. Bagshawe — cancelled all the previous instructions-that, among other things, involved giving priority in favor of the missionary society that had already been established in the area — and called upon all missionary societies to adhere to the new order. ${ }^{18}$

The new order required all mission societies to submit, when applying for rights of occupancy, six copies of applications with covering letters and sketch maps to the Assistant District Officer of Kasulu for Kasuluand all parts of Buha and five copies with sketch maps to the District Officer of Kigoma for Kigoma and all parts of the district. The sketch maps were meant to ensure that the plots applied for by missionaries were not close to the antagonistic missionary societies, that is the White Fathers and C.M.S. in Buha. All missionaries - as I will elaborate in the next section-were required not to claim further plots within a three-mile limit from another missionary society to avoid further conflicts. ${ }^{19}$ In response to the Governor's order, the Acting District Officer of Kasuluin formed Bishop Birraux about the changes to be observed by all missionaries to adhere to the new directions for acquiring rights of occupancy for all applied mission plots in Buha. He said,

I have the honour to inform you that His Excellency the Governor has directed that all Missions may not be permitted to occupy any further sites unless and until rights of occupancy have been taken out. In cases where plots have been occupied and schools have been built, applications for Rights of Occupancy in proper form must now be submitted (6 copies with covering letters and sketch maps and sketch maps to Assistant District Officer, Kasulu and in course of Uha, and 5 copies with sketch maps to the District Officer, Kigoma) for the rest of Kigoma and the directions governing the submission of such applications will be rigidly observed by all parties concerned. The Provincial Commissioner expresses his regret should any inconvenience be caused by this cancellation of all previous instructions. ${ }^{20}$

Despite the Governor's order imposing strict procedures of acquiring rights of occupancy to missionaries, there was a voluminous increase in the applications for new plots of land that showed no sign of ending. The Assistant District Officer of Kasulu noted such an increase in his letter to the Provincial Commissioner. He reported that Lutende Mission had been granted rights of occupancy but the White Fathers still had 50 other plots pending, Kakonko mission had 22, Nyaronga 15, and the C.M.S. had pending about 15 plots. Furthermore, the White Fathers were building the new mission station at Mabamba and still required new plots near the mission. What accounts for the rapid increase in the applications for new mission plots, as the Acting District Officer noted, was the advent of an administrative officer at Kibondo who made it easy for missionaries in Kibondo to process their applications there. ${ }^{21}$

Initially, all applications had to be taken to Kasulu District's headquarters, which was more than 300 kilometres from Kibondo with a rough road that posed a challenge during the rainy season. Such a distance

17 TNA 180/ C 32, Vol. 1, No. 45/39/24, Letter from the Provincial Commissioner to the District Officer, Kigoma, 18th June, 1934.

18 TNA 180/C 32, Vol. 1, No. 43/39/29, Letter from the Provincial Commissioner to Honourable Chief Secretary to the Government, 12th February, 1934.

19 See for instance, TNA 180/C 32, Vol. 1, No. C/1, 5th June, 1934.

20 TNA 180/C 32, Vol. 1, No. 190/4/41, Letter from J. Rooke Johnston, Acting District Officer to Right Rev. Bishop Birraux, 26th June, 1934.

${ }^{21}$ TNA 180/C 32, Vol. 1, No. C/4, Letter from the Assistant District Officer to the Provincial Commissioner, 25 th June, 1934. 
protracted the whole process of applying for land and granting rights of occupancy to missionaries resulting in many applications remaining unattended. The creation of the office of an administrative officer at Kibondo moved away the power from the center of the administration in Kasulu town to the mission field at Kibondo. The decentralization of administrative issues over land was a relief to missionaries, as the officer reported that for one visit he returned with about 40 new applications, and found more applications in Kasulu. ${ }^{22}$ The Assistant District Officer of Kasulu cited the White Fathers whose applications for mission plots were delayed because of the distance between Kibondo and Kasulu District headquarters. He said,

It has been customary for the White Fathers to send applications to the Boma [Kasulu District headquarters] there, where they remained in the office until an officer arrived. This has been the cause of some delay in the past in dealing with the applications... I much regret the delay in clearing up this mission land question, which had been complicated and accentuated by the presence of two rival societies. ${ }^{23}$

In addition to the creation of the office of the Assistant District Officer at Kibondo, Mr. P. E. Mitchell, the acting Chief Secretary to the government informed all the Provincial Commissioners about the newly approved procedures to be used when granting rights of occupancy to missionaries. The new procedures, as the acting Chief Secretary contended, were meant to "clear out confusion and avoiding further complications" for missionaries. ${ }^{24}$ The first procedure warned missions that there would be no rights of occupancy to be granted and no missionary society could claim right to ownership of land over a village school staffed by a mission at the request of the villagers themselves to build the school. The procedure further stressed that rights of occupancy could not be granted to the village school even if missionaries took part in erecting such a school. Second, all missionary applications should be supported with sketch plans and all should be submitted to the District Commissioner where they should be forwarded by the Provincial Commissioner to the Land Officer with an annual report. Third, the new circular authorized the Provincial commissioner, without the Governor's approval, to issue rights of occupancy to the Native Authorities with intention to build schools on their own land. He had also the power to issue rights of occupancy to all applications of less than three acres of land. ${ }^{25}$

Although missionaries were supposed to submit, in their applications, sketch maps of their intending projects at the proposed mission stations, problems between rival missionaries, that is the White Fathers and C.M.S., continued in Buha. Such problems were revealed by A. Jeffrey, who on behalf of the Acting Chief Secretary informed the Provincial Commissioner of the Western Province that there was a considerable difficulty in handling the applications of missionary societies due to the absence of maps of concerned areas. He stressed that the sketch maps or plans of actual sites were of less assistance in assessing the claims of the rival missions within a particular district. He therefore strongly encouraged that in the future, all missionaries - in this case, the White Fathers and C.M.S. missionaries-should accompany their applications with a simple outline map of the area, showing the situation of various mission schools, hospitals, tribal areas and the actual site. The map had to be on a definite scale to allow easy gauging of the distances between rival missions. $^{26}$

22 TNA 180/ C 32, Vol. 1, No. C/4.

23 TNA 180/C 32, Vol. 1, No.190/4/41.

24 TNA 180/C 32, Vol. 1, No. 22252/114, letter from P. E. Mitchell, the Acting Chief Secretary to the Province Commissioner, 30 July, 1934.

25 TNA 180/C 32, Vol. 1, No. 22252/114.

26 TNA 180/C 32, Vol. 1, No. 13330/154, Letter from A. Jeffrey, on behalf of the Chief Secretary, to the Provincial Commissioner, Western Province, 1st December, 1934. 
Jeffrey's circular on the difficulty of handling land issues over rival missionaries was followed up by the three-mile limit instruction to keep schools of missions at a considerable distance. The Provincial Commissioner ordered the District Commissioners to adhere to the three principles that intended to maintain the three-mile limit of missionary schools. First, in areas where missionaries wanted to establish schools, and there was a danger of causing problems such as it was the case for Kasulu town it was suggested that no school was to be allowed within the three miles of the town. This was due to the fact that C.M.S. had already established themselves in the town and that the presence of the White Fathers could cause problems if they were to be allowed to open up their mission station in the town. ${ }^{27}$ Second, the acting Chief Secretary-G. F. Sayers-issued a government circular of 1937 that required all schools to be registered and the failure to do so would result in a penalty as outlined by the African Education (Amendment) Ordinance of 1936. The acting Chief Secretary further insisted that new schools should be registered by the Director of Education, subject to meeting all the requirements. Finally, following the enactment of the African Education (Amendment) Ordinance, the Director of Education was no longer entitled to register religious or catechist institutions in the territory. ${ }^{28}$ Reasons for this decision remain unclear in the surviving documents. However, the decision might have been reached as a strategy to cope with ending mission rivalries in the colony.

As to the powers of the Provincial Commissioner - as stated in a letter of 30th July, 1934 on the rights of occupancy the acting Chief Secretary to the Government - G. F. Sayers-issued a new circular that limited the powers of Provincial Commissioners in granting rights of occupancy to the period of not more than five years. That meant that applications for longer terms were to be forwarded to the Acting Chief Secretary of the Government through the Director of Lands and Mines. ${ }^{29}$ Furthermore, the power to refuse any application for a right of occupancy was reserved to the Governor of the whole territory of Tanganyika and it was not intended to be delegated to Provincial Commissioners. Thus, the refusal of applications for both short and long terms had to be submitted with supporting reports and recommendations to the Acting Chief Secretary through the Director of Lands and Mines in Dar es Salaam for the governor's approval or disapproval. ${ }^{30}$

\section{The White Fathers, the Land Question, and Native Affairs: Kakonko Mission, 1937-1953}

Besides the White Fathers' confrontations with the C.M.S. missionaries, their desire to have more mission plots at Kakonko fuelled tensions with natives that led to government intervention. On December 07, 1937, Msgr. Jan van Sambeek of the vicariate apostolic of Tanganyika applied for ten (10) acres of land at Kakonko which were closer to the White Fathers mission plots. The land was to be used by the White Sisters for medical, educational and religious purposes. The two natives who were living on the claimed land had declared themselves ready to move for an indemnity [100 shillings were paid by Monsignor Sambeek to compensate the two cultivators]. ${ }^{31}$ However, the application was not given due response by the Land Officer, notwithstanding the Bishop's intention to finish the houses for the White Sisters in two years. As a result he was forced to write a letter to the Land Officer, Mr. Johnston, inquiring about a reply to his application. ${ }^{32}$ The disbursement of the

27 TNA 180/C 32, Vol. 1, No. 45/39/38, Letter of the Provincial Commissioner to the District Officer, Kigoma, 17th December, 1934.

28 TNA 180/C 32, Vol. 1, S.M.P. 22463, Government Confidential Circular No. 5 of $2^{\text {oth }}$ November, 1937.

29 TNA 180/C 32, Vol. 1, Government Circular No.1 of 27th February, 1938.

30 TNA 180/C 32, Government Circular No. 1.

31 TNA 20/78.523, Letter of Msgr. Jan van Sambeek to the Land Officer, Dar es Salaam 7/12/1937.

32 TNA 20/78.523, Letter of Msgr. Jan van Sambeek to Mr. Johnston, Ujiji, 21/3/1938, R. B. Richardson to the Director, Department of Land and Mines, Tanganyika Territory, Dar es Salaam, 26/3/1938. 
money to the natives put Msgr. Sambeek in trouble with the colonial state that in turn protracted the whole process of applying for the plots. In his letter of approval, the Chief Secretary ordered the Provincial Commissioner of the Western Province to provide justifications for the amount of money that was paid without the Governor's consent. He said,

... in this connection, it is noted from the District Officer's report it would appear that the natives concerned have already been approached and have actually been paid compensation without entering into the formal agreement prescribed and without the Governor's approval and I am to ask you to explain the reason for this departure from the prescribed procedure. $^{33}$

With this note, the Provincial Commissioner commanded the District Officer for Kigoma, Mr. J. R. Johnston, to provide reasons for the compensation made by the White Fathers. The only reason that the District Officer provided for such a departure (mistake) was the fact that missionaries did not abide by the legal procedure. "The reason why this compensation was paid before the Governor approved is that the White Fathers are ignorant of the law ...."34 The assessment for the claimed plots was mistakenly described by the District Commissioner. He had in his original report stated that there were two natives on the plot cultivating with a few goats. Mr. L. H. L. Foster's letter to the District Officer shows that there were four men, each owning a house and cultivating with a few goats. It is this misreporting that prompted the District Commissioner to require satisfactory explanations before an agreement of removing the natives in favour of the White Fathers could finally be concluded. ${ }^{35}$ This problem made the White Fathers keep on waiting for quite long until the acting Chief Secretary to the Colonial state was compelled to remind the Provincial Commissioner about the White Fathers' claim. Eventually, missionaries were granted the right of occupancy over ten acres on February 20th, 1939, following the fulfilment of the conditions to which they were required to adhere. These included: 20 shillings for the first year rent, 102 shillings for preparation and registration of the title deed and 500 shillings that covered the cost for survey. All these were paid by the White Fathers on February 1st, 1939. ${ }^{36}$

Although the Bishop was granted the rights of occupancy over ten acres for his mission station it seemed that they could not meet his desire to evangelize the natives in the area. Hence on July 21st, 1952, Msgr. Jan van Sambeek again applied for extension of the land where he could set up the middle school. However, the District Commissioner for Kibondo investigated the claimed land and he was dissatisfied with the position of the Africans who were living in the area, for they had been living and tilling land for more than nineteen years. ${ }^{37}$ In cognizance of the real situation of the claimed land, the District Commissioner informed the Provincial Commissioner, who proposed that the White Fathers look for a completely new and smaller site, as it was impossible for the colonial state to evacuate the natives.

\footnotetext{
33 TNA 20/78.523, Letter from the Acting Chief Secretary to the Provincial Commissioner of Western Province 10/4/1938.

34 TNA 20/78.523, R. B. Richardson (Provincial Commissioner) to the District Officer 4/6/1938.

35 TNA 20/78.523, L. H. L. Foster to the District Officer of Kigoma District 27/9/1938, 5/10/1938, see also a letter from Gruise William (Provincial Commissioner) to the District officer 9/11/1938.

36 TNA 20/78.523, Letter from the Acting Chief Secretary to the Provincial Commissioner 18/11/1938. The first reminder was made on 1/7/1938, see a letter from D. R. MacDonald, the Acting Land Officer of Kigoma, 3/7/1939, C. C. O'Hocan, Acting District Officer (Kigoma) to the Director of Land and Mines, Dar es Salaam, 20/02/1939.

37 TNA 25143.29, Letter from the District Commissioner (Kibondo) to the Provincial Commissioner of the Western Province, $7 / 10 / 1952$
} 
$\ldots$ it appears that only $16 \frac{1}{2}$ acres are available there and not 35 as required as the minimum holding for a middle school. I don't know the area myself, but if we are going to whittle down the standards of the agricultural holdings for middle schools then the whole policy for these schools may be nullified. I should think in the circumstances it would be better for the mission to look for a completely new site since neither the DC nor myself are prepared to turn off the locals in order to enable the mission obtain the site of land required. ${ }^{38}$

However, the White Fathers did not provide an alternative site for the establishment of the middle school and this implied the removal of the people in question. Some Africans did not leave their plots; they strongly resisted and retained their plots against the White Fathers' intention of extending up to 35 acres their land-holding at Kakonko. Among the Africans who strongly opposed them was Mihigo, who was regarded by the White Fathers as a "stubborn old man". To address this challenge, the Provincial Commissioner urged the District Commissioner to ensure that the land of that old man was left untouched. ${ }^{39}$ Secondly, the White Fathers were told to submit fresh plans to take in the additional land required that would give them a total of the needed 35 acres. Thirdly, the District Commissioner was ordered to consult the people in the course of earmarking the new plot and setting up new arrangements, to compensate the people before they were moved from their land. ${ }^{40}$ As a result, Fr. Harvey (Father Superior of Kakonko) agreed to compensate the Africans who were willing to vacate their land and such compensation had to be fixed in discussion and in agreement with Fr. Harvey, Mwami Wakili Ramadhani of Buyungu, the men concerned and the District Commissioner, ${ }^{41}$ while the old man (Mihigo) who had resisted moving, would stay and cultivate parts of his plot until he died when his plot would be free.

The actual owner by his name is Mihigo; he is an old man and broken man whom it should be a pity to have him moved now... the old man will stay on the land as long as he lives and cultivates parts of the plot for himself. What will be left will be used by the middle school boys for the time being. At his death, the plot will absolutely be free. Then Mihigo has been told by Mwami that he should not lend to others parts of his field as from the beginning of the next rain season. There are actually 4 or 5 men cultivating patches of this land. Again those have been told that from November next, they will not be allowed to cultivate there ... so the main thing is to ensure the possession of that plot .... ${ }^{42}$

In addition to the above decision, the colonial state ordered the White Fathers to safeguard the interests of the man (Mihigo) by paying him 100 shillings and building him another hut before his old hut was removed. ${ }^{43}$ But before this was done, the Provincial Commissioner refused to approve the other White Fathers' claim for more than 35 acres (a minimum of 50 acres) to run their mission, claiming that they had not submitted a formal application. To avoid further protracted correspondences, Fr. Harvey submitted his formal application for an extension of 40 acres for the middle school. He stipulated how he would pay Mihigo the sum of 100 shillings for his hut to be removed. ${ }^{44}$ Following the formal submission, the White Fathers were granted the rights of occupancy over 40 acres at Kakonko in August $1953 .{ }^{45}$

\footnotetext{
38 TNA 25143.30, Letter from the Provincial Commissioner (Western Province) to the Education Officer in Tabora, 30/10/1952, TNA 25143, Letter from Ednspec to the Provincial Education Officer, 4/11/1952.

39 TNA 25143.33, Letter from the District Commissioner to the Provincial Commissioner, 4/12/1952, TNA 25143.34, Letter from the Provincial Commissioner to Mr. T. O. Pike, District Commissioner (Kibondo), 30/12/1952.

40 Ibid.

41 TNA 25143.36, Letter from the District Commissioner (Kibondo) to the Provincial Commissioner 4/02/1953, Mr. G. R. P. Henton (District Officer) to the Provincial Commissioner, 28/03/953.

42 TNA 25143.37, Letter from Fr. Harvey (Kakonko Mission) to the District Commissioner (Kibondo) 22/1/1952.

43 TNA 25143.40, Letter from Mr. G. R. P. Henton to the Provincial Commissioner, 28/03/1953.

44 TNA 25143.42, Letter from the Provincial Commissioner to the District Officer (Kibondo), 17/04/1953, TNA 25143.50, Letter from G. A. Lusby (District Commissioner) to the Senior Provincial Commissioner 19/6/1953.

45 TNA 25143.52, Telegram from the Land Survey (Dar es Salaam) to Kibondo District.
} 


\section{Conclusion}

My paper has examined the land question and how it changed Catholic-Anglican relations in Buha in Western Tanzania in the late colonial period. The paper has demonstrated how issues of land remained in the late-colonial period one of the unsettled problems, and in some mission stations, impeded the activities of both the White Fathers and C.M.S. missionaries. The paper has concentrated on four issues. First, it has presented an account of the struggle for land between the White Fathers and C.M.S. missionaries in various areas of Buha and the consequent tensions among the two missionary societies. Second, the paper has explored government response to land-related problems in its attempt to address tensions between the White Fathers and C.M.S. Third, the paper has explored the provision of rights of occupancy and how, in some areas, colonial government officials delayed or manipulated their power by issuing rights of occupancy to missionaries who had voiced their concerns over the area. Finally, the paper has also provided an account of the land question centering on the White Fathers and native affairs that needed government intervention, to demonstrate the fact that land issues in Buha were multifaceted and were not confined to the relations between the White Fathers and the C.M.S. missionaries. Rather, in some areas, land-related issues drew missionaries into problems with natives that also called for government attention.

\section{References}

\section{A: Secondary Sources}

Ceillier, J.-C. (2008). Histoire des Missionnaires d'Afrique (Pères Blancs) e la fondation par Mgr Lavigerie à la mort du fondateur (1868-1892). Paris: editions Karthala.

Ceillier, J.-C. (2011). History of the missionaries of Africa (White Fathers): From the beginning of their foundation by Msgr. Lavigerie until his death. Translated from French by Aylward Shorter. Nairobi: Paulines Publications Africa.

Grant, C. H. B. (1925). Uha in Tanganyika territory. The Geographical Journal, 66(5).

Lucas, M. (1987). Introduction to the history of Christianity in Africa. Kipalapala: Tanganyika Mission Press.

Nolan, F. P. (1978). Mission to the Great Lakes: The White Fathers in Western Tanzania 1878-1978. Kipalapala: Tanganyika Mission Press.

Nolan, F. P. (2012). The White Fathers in Colonial Africa, 1919-1939. Nairobi: Paulines Publications Africa.

Kakete, S. et al. (1985). Kanisa la PentekosteBigabiro, Jubilii 1935-1985. Bigabiro: Unpublished Manuscript.

Hugo, H. (2007). Footsteps on the Sands of Time: A life of Bishop Jan van Sambeek. Rome: Society of Missionaries of Africa-History Series No. 8.

Georg, L., \& Matanwa, L. (1979). Miaka Mia Jimboni Kigoma 1879-1979. Kipalapala: Tanganyika Mission Press.

Paulhus, J. (1994). Go to my people: Missionaries in Tanzania, 1894-1994. Missionary Sisters of Our Lady of Africa.

Scherer, J. H. (1959). The Ha of Tanganyika, Anthropos, Bd. 54, H.5./6.1959.

Van de Pas, P. (2010). A history of the White Fathers in Western Tanzania: Their work in the Vicariate of Tanganyika with special emphasis on today's Diocese of Sumbawanga and Mpanda, 1878-2002. Dar es Salaam: Atiman House.

(anonymous). (1938). Directoire pour l'observance des Constitutions des Sœurs Missionnaires de Notre-Dame d'Afrique. Alger.

\section{B: Primary Sources: Tanzania National Archives (TNA)}

TNA 180/C32 Vol. 1, Letter to Honourable, the Chief Secretary to the Government, Tanganyika Territory, Confidential No. 43/39/22 Jan 3rd, 1934.

TNA 180/C 32 Vol. 1, No. 43/39/22 Jan 3rd, 1934, Mr. Woodhouse's reply to F. J. Bagshawe on behalf of the Acting Governor, Tanganyika Territory.

TNA 180/C 32 Vol. 1, Letter to the Honourable the Chief Secretary to the Government, Tanganyika Territory, Confidential No. 43/39/22 Jan 3rd, 1934.

TNA 180/C 32, Vol. 1, No. 43/39/29, 12th February, 1934.

TNA 180/C 32, Vol. 1, No. 45/39/17, Letter from the Provincial Officer to the Honourable Land Officer, Tanganyika Territory, 26th April, 1934. 
TNA 180/C 32, Vol. 1, No. C/1, Letter from the Assistant District Officer of Kasulu to the Provincial Commissioner, 5th June, 1934.

TNA 180/ C 32, Vol. 1, No. 45/39/24, Letter from the Provincial Commissioner to the District Officer, Kigoma, 18 th June, 1934.

TNA 180/C 32, Vol. 1, No. 43/39/29, Letter from the Provincial Commissioner to Chief Secretary to the Government, 12th February, 1934.

TNA 180/C 32, Vol. 1, No. 190/4/41, Letter from J. Rooke Johnston, Acting District Officer to Right Rev. Bishop Birraux, 26th June, 1934.

TNA 180/C 32, Vol. 1, No. C/4, Letter from the Assistant District Officer to the Provincial Commissioner, 25 th June, 1934.

TNA 180/C 32, Vol. 1, No. 22252/114, Letter from P. E. Mitchell, the Acting Chief Secretary to the Province Commissioner, 30 July, 1934.

TNA 180/C 32, Vol. 1, No. 13330/154, Letter from A. Jeffrey, on behalf of the Chief Secretary, to the Provincial Commissioner, Western Province, 1st December, 1934.

TNA 180/C 32, Vol. 1, No. 45/39/38, Letter of the Provincial Commissioner to the District Officer, Kigoma, 17th December, 1934.

TNA 180/C 32, Vol. 1, S.M.P. 22463, Government Confidential Circular No. 5 of 20th November, 1937.

TNA 180/C 32, Vol. 1, Government Circular No. 1 of 27th February, 1938.

TNA 20/78.523, Letter of Msgr. Jan van Sambeek to the Land Officer, Dar es Salaam, December 7th, 1937.

TNA 20/78.523, Letter of Msgr. Jan van Sambeek to Mr. Johnston, Ujiji, March 21st, 1938. TNA 20/78.523, Letter of R. B.

Richardson to the Director, Department of Land and Mines, Tanganyika Territory, Dar es Salaam, 26/3/1938.

TNA 20/78.523, Letter from the Acting Chief Secretary to the Provincial Commissioner of Western Province, April 10 th, 1938.

TNA 20/78.523, R. B. Richardson (Provincial Commissioner) to the District Officer, June 4th, 1938.

TNA 20/78.523, L. H. L. Foster to the District Officer of Kigoma District, September 27, 1938, \& October 5th, 1938.

TNA 20/78.523, Letter from Gruise William (Provincial Commissioner) to the District officer, November 9th, 1938.

TNA 20/78.523, Letter from the Acting Chief Secretary to the Provincial Commissioner, November 18th, 1938.

TNA 25143.29, Letter from the District Commissioner (Kibondo) to the Provincial Commissioner of the Western Province, October 7th, 1952.

TNA 25143.30, Letter from the Provincial Commissioner (Western Province) to the Education Officer in Tabora, October 30th, 1952.

TNA 25143, Letter from Ednspec to the Provincial Education Officer, November 4th, 1952.

TNA 25143.33, Letter from the District Commissioner to the Provincial Commissioner, December 4th, 1952.

TNA 25143.34, Letter from the Provincial Commissioner to Mr. T. O. Pike, District Commissioner (Kibondo), December 30th, 1952.

TNA 25143.36, Letter from the District Commissioner (Kibondo) to the Provincial Commissioner, April 4th, 1953.

TNA 25143.36, Mr. G. R. P. Henton (District Officer) to the Provincial Commissioner, March 28th, 1953.

TNA 25143.37, Letter from Fr. Harvey (Kakonko Mission) to the District Commissioner (Kibondo), January 22 nd, 1952.

TNA 25143.40, Letter from Mr. G. R. P. Henton to the Provincial Commissioner, March 28th, 1953.

TNA 25143.42, Letter from the Provincial Commissioner to the District Officer (Kibondo), April 17th, 1953.

TNA 25143.50, Letter from G. A. Lusby (District Commissioner) to the Senior Provincial Commissioner, June 19 th, 1953. 